\title{
Model Tata Kelola Administrasi Pemerintahan Yang Baik di Daerah Otonom Baru
}

\author{
Yulia Neta \\ Dosen dan Ketua Bagian Hukum Tata Negara Fakultas Hukum Unila
}

\begin{abstract}
Abstrak
Tujuan penelitian adalah menghasilkan model tatakelola administrasi pemerintahan yang baik di Kabupaten Pesawaran sebagai Daerah Otonom Baru.. Penelitian ini dilakukan mulai Mei sampai November 2011 meliputi survay lapang dan analisis di laboratorium. Pekerjaan lapang dilakukan di Kabupaten Pesawaran sebagai daerah otonom baru (DOB). Data di petik melalui wawancara terhadap para key informan. Selain itu data diperoleh dari berbagai dokumen pendukung dan hasil-hasil penelitian pendahuluan yang relevan, dan sebagainya. Hasil penelitian tahun pertama ini adalah :1.Tatakelola administrasi pemerintahan yang baik di Kabupaten Pesawaran melalui pelayanan publik di bidang kependudukan dan catatan sipil antara lain pelatihan tenaga teknis SIAK, pemutahiran data penduduk, pelatihan/diklat bagi tugas pendaftaran penduduk dan diklat aparatur dibidang Administrasi Kependudukan serta penerapan pprogram e-KTP 2. pelayanan publik di bidang pendidikan antara lain penyetaraan kualitas pendidikan, pelaksanaan program life skill pada semua sekolah sehingga dapat menghasilkan sumber daya manusia berkualitas yang siap pakai dalam menghadapi dunia kerja, melaksanakan rekruitmen terbuka untuk memperoleh tenaga pendidik yang memiliki spesifikasi latar pendidikan yang tepat, peningkatan pembangunan unit gedung baru, ruang kelas baru dan rehabilitasi gedung sekolah, peningkatan pengadaan sarana pendidikan seperti alat pendidikan dan alat laboratorium di semua jenis jenjang pendidikan untuk mendukung program peningkatan kualitas dan relevansi tenaga kependidikan. 3.di bidang kesehatan masyarakat melalui penyempurnaan manajemen pelaksanaan program yang meliputi perencanaan, pengorganisasian, pelaksanaan dan pengawasan untuk mencapai tujuan yang efektif dan efisien, meningkatkan profesionalisme dan kualitas tenaga kesehatan dalam rangka meningkatkan kualitas pelayanan kepada masyarakat, meningkatkan advokasi ke Pemerintah Daerah dan Dinas Kesehatan Provinsi serta Kementerian Kesehatan untuk meningkatkan pemenuhan sumberdaya khususnya pembiayaan kesehatan, meningkatkan pemberdayaan masyarakat dan sektor swasta untuk lebih meningkatkan peran sertanya dalam pelaksanaan pembangunan kesehatan, serta meningkatkan upaya preventif dan promotif dalam pelaksanaan program pembangunan kesehatan.
\end{abstract}

Kata Kunci: model, tata kelola, pemerintahan yang baik, pelayanan publik.

\section{PENDAHULUAN}

Tata kelola pemerintahan yang administrasi

baik yang mencerminkan karakteristik good govenrment dan clean governance merupakan hal yang sangat penting peranannya dalam perencanaan 
kegiatan pembangunan, baik di tingkat nasional, daerah, maupun desa Karena setiap perencanaan pembangunan membutuh-kan data dan informasi yang tepat.

Prinsip good governance dalam proses penyelenggaraan pemerintahan daerah merupakan sebuah tuntutan bagi pemerintah daerah dalam rangka mewujudkan pemerintahan yang demokratis, bersih, transparan, dapat di pertanggungjawabkan, efektif dan efisien. Tekad untuk mewujudkan prinsip good governance juga didasari oleh fakta peran birokrasi pemerintah daerah yang belum optimal memberikan pelayanan publik secara prima kepada masyarakat

Kabupaten Pesawaran dengan luas wilayah 2.243,51 $\mathrm{km}^{2}$ yang diresmikan menjadi daerah otonom baru (DOB) pada 17 Juli 2007. Sebagai penyelenggara pemerintahan tingkat Kabupaten, dalam melaksanakan tugas pokok dan fungsinya, sudah tentu memerlukan suatu fasilitas (sarana dan prasarana) yang memadai, adanya perangkat peraturan tentang pelaksanaan administrasi pemerintahan, pedoman administrasi pemerintahan, maupun pembinaan dan pengawasan dalam pelaksanaan administrasi pemerintahan sehingga tugas umum pemerintahan dan pembangunan dapat tercapai dengan efektif dan efisien.

Hasil studi yang dilakukan Kagungan, dkk (2008), sebagai daerah otonom baru (DOB), tata kelola administrasi pemerintahan di kabupaten Pesawaran belum terlaksana dan terwujud dengan baik, dalam penyelenggaraan administrasi pemerintahan untuk tingkat desa/pekon masih ditandai dengan kurangnya koordinasi antara aparat desa dalam menjalankan tugas administrasi, dalam menjalankan tugas seringkali terjadi tumpang tindih, hal ini dikarenakan job description yang tidak jelas. Padahal dengan segala keterbatasan yang dimiliki dan sebagai tulang punggung dalam praktek penyelenggaraan pemerintahan di Indonesia, pemerintah desa/pekon dituntut untuk bisa melaksanakan dan mengelola aspek-aspek administrasi negara tersebut agar dapat memberikan pelayanan yang baik kepada masyarakat.

Kunci dari semua permasalahan tersebut di atas adalah antara lain pada peningkatan kapasitas aparatur melalui berbagai kegiatan pelatihan, penguatan fungsi berbagai kelembagaan yang dapat mengakomodir aspirasi dan mengimplementasikan pengetahuan dan kearifan lokal masyarakat setempat, yang selama ini hanya menjadi tatanan kebijakan non formal (aturan tidak tertulis) menjadi sebuah kebijakan secara formal, karena tata kelola administrasi pemerintahan yang baik untuk tingkat desa sekalipun, akan mencerminkan suatu pemerintahan yang efektif dan efisien, sehingga hasil-hasil pembangunan yang dicapai benar-benar mencerminkan aspirasi masyarakat yang dapat mewujudkan cita-cita dan tujuan negara secara keseluruhan khususnya di Kabupaten Pesawaran.

Berdasarkan uraian tersebut permalasahannyaa adalah bagaimana reformasi pelayanan publik di Kabupaten Pesawaran, dan faktor apa yang mempengaruhi pelayanan publik? 


\section{PEMBAHASAN}

\subsection{Reformasi birokrasi melalui pemberian pelayanan publik di Kabupaten Pesawaran sebagai Daerah Otonom Baru (DOB)}

\section{a. Bidang Kependudukan dan Catatan Sipil}

Sebagai daerah otonom baru, Kabupaten Pesawaran mengalami permasalahandalam pelaksanaan program kegiatan Kependudukan dan Catatan Sipil.

Permasalahan yang dihadapi dalam pelaksanaan program kegiatan Kependudukan dan Catatan Sipil sebagai berikut :

1. Kurangnya SDM dalam rangka pengoprasian/peng-input-an data SIAK.

2. Kurangnya tenaga teknis komputer SIAK bila terjadi kerusakan sistem.

Adapun upaya mengatasi berbagai kendala/masalah tersebut, antara lain telah ditempuh dengan berbagai strategi yaitu melalui:

a. Pelatihan tenaga teknis SIAK.
b. Pemutahiran Data
Penduduk/Data Base melalui
Teknologi SIAK Off-Line.
c. Mengadakan pelatihan/diklat
petugas pendaftaran penduduk
dan diklat aparatur dibidang
Administrasi Kependudukan
Berkenaan dengan pelaksanaan program e-KTP (Kartu Tanda Penduduk elektronik) atau Single Identity Number

(SIN) direncanakan rampung akhir tahun 2012. Seluruh penduduk Indonesia saat itu diharapkan sudah memiliki $e$ -KTP sebagaimana yang disampaikan Menteri Dalam Negeri RI, Gamawan Fauzi. Dengan penerapan e-KTP diharapkan tidak ada lagi penduduk yang bisa menggunakan KTP ganda. Dari segi keamanan, e-KTP menggunakan expert-expert dari ITB, BPPT, dan sandi negara yang didukung 15 Kementerian dan lembaga yang ikut membidani. Data $e$-KTP nantinya akan terkoordinasi dengan sejumlah Kementerian dan lembaga serta dapat digunakan untuk mendeteksi sejumlah tindak kejahatan (terorisme, dsb), data untuk kesehatan, untuk paspor.

Program e-KTP memiliki manfaat sebagai berikut : (i) Mencegah dan menutup peluang adanay KTP ganda dan KTP palsu sehingga memberikan rasa aman dan kepastian hukum bagi masyarakat, menutup pelaku kriminal termasuk teroris yang selalu menggunakan KTP ganda, (ii) KTP elektronik sudah memenuhi semua ketentuan yang diatur dalam Undang-Undang Nomor 23 Tahun 2006 dan Peraturam Presiden Nomor 26 Tahun 2009 sehingga berlaku secara Nasional dan tidak memerlukan KTP setempat. Menurut Kepala Bidang Kependudukan Kabupaten Pesawaran, pelaksanaan program eKTP di Kabupaten Pesawaran berjalan sesuai ketentuan yang ditetapkan Pemerintah Pusat.

Masih berkenaan dengan layanan publik yang berhubungan dengan e-KTP di Kabupaten Pesawaran sebagai DOB, Dinas Kependudukan dan Catatan Sipil telah melakukan sosialisasi kepada masyarakat, menunggu pengadaan alat dan kelengkapan lainnya. Untuk mengoptimalkan penerapan e-KTP, Dinas Kependudukan dan Catatan Sipil Kabupaten Pesawaran mengadakan pelatihan pegawai Kecamatan. Ini diperlukan untuk 
melayani masyarakat yang memerlukan e-KTP. Setelah proses perekaman selesai, hasilnya akan dirasionalisasikan dengan data hasil pemutakhiran tahun 2010 oleh Kementerian Dalam Negeri. "Masing-masing warga dapat mengganti KTP lama dengan e-KTP" Dalam proses ini masing-masing warga akan melalui tahap verifikasi lanjutan dengan mencocokkan sidik jari seperti yang dilakukan saat perekaman" Hal ini untuk membuktikan bahwa warga bersangkutan memang benar-benar pemilik e-KTP yang dimaksud dalam database," demikian sebagaimana yang diungkapkan Kepala Bidang Kependudukan Kabupaten Pesawaran.

\section{b. Bidang Kesehatan}

Visi Dinas Kesehatan Kabupaten Pesawaran "Menuju Kabupaten Pesawaran Yang Mandiri Untuk Hidup Sehat"

Misi Dinas Kesehatan

Kabupaten Pesawaran

1. Menurunkan resiko kesakitan dan kematian

2. Mencegah meningkatnya resiko penyakit dan masalah kesehatan

3. Meningkatkan kemitraan dan pemberdayaan masyarakat

4. Meningkatkan pelayanan kesehatan secara merata, terjangkau dan bermutu bagi masyarakat

5. Merumuskan kebijakan dan memantapkan manajemen untuk meningkatkan kinerja pelayanan kesehatan

\section{Anggaran} Kesehatan
Aspek ini merupakan salah satu permasalahan pokok bagi penyelenggaraan kesehatan di Kabupaten Pesawaran. Pola alokasi dana alokasi dari pemerintah pusat yang masih digabungkan dengan kabupaten Lampung Selatan (Kabupaten Induk sebelum pemecahan), ternyata memberi pengaruh terhadap proses pengucuran pada tingkat Kabupaten Pesawaran menjadi lambat. Tidak hanya dihadapkan kepada proses yang bertingkat tersebut, kuantitas dana alokasi yang masih sangat minim juga menjadi masalah yang rumit ketika dihadapkan kepada berbagai prioritas penting sebagai sebuah Daerah Otonom Baru.

\section{Efektivitas dan Efisiensi Pelayanan}

Kondisi sumber daya yang terdapat pada saat ini menunjukkan bahwa masih terdapat kendala dan tantangan bagi proses penyelenggaraan pelayanan kesehatan. Jika melihat kondisi infrastruktur yang masih dihadapkan kepada masalah kecukupan dan kelayakan sarana gedung, masalah ketersediaan sarana peralatan dan pendukung pelayanan, kuantitas tenaga kesehatan dan distribusi anggaran operasional yang masih minim dan terhambat oleh proses anggaran, maka dapat dirangkum bahwa hal tersebut mempengaruhi derajat efektifitas kegiatan layanan kesehatan secara menyeluruh. Kondisi tersebut mempengaruhi jalannya proses penyelenggaraan layanan kesehatan yang semestinya dapat berjalan dengan optimal.

Sebagai sebuah daerah otonom baru (DOB), Kabupaten Pesawaran juga memiliki pilihan solusi yang 
terbatas untuk mengatasi kondisi sumber daya yang belum berada pada tingkat memadai. Namun demikian, dapat diketahui juga adanya beberapa langkah yang dilakukan oleh pemerintah kabupaten guna mengatasi berbagai permasalahan tersebut. Dalam hal ketersediaan tenaga kesehatan, langkah yang dilakukan berupa rekrutmen dokter PTT dan tenaga sukarela yang memenuhi syarat serta melaksanakan rekruitmen terbuka untuk memperoleh tenaga kesehatan yang memiliki spesifikasi latar pendidikan yang tepat. Langkah yang dapat dilakukan dalam persoalan anggaran operasional yang terbatas adalah melalui pengajuan alokasi DAK pada tahun selanjutnya yang lebih merinci kebutuhan kondisi kebutuhan pelayanan kesehatan di daerah Pesawaran secara lebih detail. Namun demikian, upaya yang dilakukan oleh pemerintah kabupaten ini juga masih menunjukkan ketergantungan terhadap bantuan dari pemerintah pusat. Solusi konvensional yang justru menunjukkan bahwa daerah otonom baru memang sangat tergantung terhadap bantuan dari pemerintah pusat.

Sumber daya yang terdapat hingga saat ini di wilayah pesawaran memang diakui sudah tidak maksimal lagi untuk digunakan. Sumber daya infrastruktur tidak maksimal untuk digunakan secara jangka panjang karena pemeliharaan dan perawatan yang kurang dilakukan secara tetap. Sementara untuk mengatasi kondisi kurang baik aset itu, pemerintah Kabupaten Pesawaran menghadapi kendala anggaran yang masih sangat terbatas. Anggaran yang diperoleh pada tahun anggaran pertama dan kedua sejak pemekaran, masih diperuntukkan bagi kebutuhan pembangunan perkantoran pemerintah kabupaten dan dana rutin seperti gaji pegawai dan sejenisnya.

Alokasi dana yang diperuntukkan bagi kepentingan pembangunan spesifik bidang pendidikan dan kesehatan masih sangat minim dan belum mampu melingkupi seluruh kebutuhan perbaikan dan perawatan infrastruktur dan sarana pendidikan pada sekolah-sekolah ataupun sarana medis pada puskesmas-puskesmas. Masalah anggaran ini juga yang menjadi alasan untuk membuat program-program yang dapat memberi pengaruh terhadap peningkatan kapasitas tenaga pendidik dan kesehatan yang terdapat pada wilayah Pesawaran. Fasilitas kesehatan yang terdapat pada wilayah Kabupaten Pesawaran tersebar pada seluruh kecamatan, hanya saja pada beberapa kecamatan masih ditemui kondisi fasilitas yang masih minim.

Ada Kecamatan Punduh Pidada yang diantara wilayahnya berupa pulau-pulau berpenghuni misalnya, diakui bahwa kondisi sekolah masih perlu banyak perbaikan. Penyebaran kondisi prasarana yang belum merata tersebut diakibatkan kebijakan pada masa sebelumnya yang dianggap belum didistribusikan secara adil dan rata.

Luasnya wilayah kabupaten Lampung Selatan sebagai Kabupaten induk pada masa lalu menghasilkan masih adanya kondisi prasarana yang minim. Oleh karena itu, adanya pemekaran daerah dianggap memberi kesempatan adanya pemerataan bagi kesehatan di wilayah kabupaten baru ini. Selama dua tahun Kabupaten Pesawaran dimekarkan, pemerintah 
daerah belum mampu untuk melakukan kebijakan yang dapat mengatasi atau merubah kondisi tersebut secara signifikan. Kondisi anggaran yang masih minim dan masih tergantung kepada pemerintah pusat merupakan faktor yang menjadi penyebab masih adanya kondisi tersebut.

\section{Pemerataan Kesehatan}

Pelayanan

Kabupaten Pesawaran yang memiliki wilayah seluas 2.243,51 $\mathrm{km}^{2}$, terdiri dari tujuh Kecamatan, yaitu: (1). Gedong Tataan, (2). Kedondong, (3). Negeri Katon, (4). Padang Cermin, (5). Punduh Pidada, (6). Tegineneng, dan (7). Way Lima. Ketujuh kecamatan tersebut memiliki latar belakang kondisi geografis dan infrastruktur utama yang bervariasi. Beragamnya latar belakang kondisi itu memberikan implikasi terhadap berkembangnya secara berbeda kondisi fasilitas dan ketersediaan sumber daya manusia. Pada wilayah kecamatan yang sudah lebih dahulu berkembang seperti Gedong Tataan dan Tegineneng diakui bahwa kondisi infrastruktur pendidikan dan kesehatan pada kecamatan ini nampak lebih memadai apabila dibandingkan dengan Padang Cermin, Punduh Pidada dan Negeri Katon. Kondisi yang terbentuk secara berbeda tersebut dihasilkan dari kondisi geografis yang cenderung memiliki akses yang kurang memadai, ketersediaan listrik dan telekomunikasi yang belum dapat terlalu diandalkan dan kondisi sosial ekonomi wilayah setempat yang belum terlalu berkembang dengan baik.

Kondisi dari masing-masing kecamatan yang berbeda tersebut yang juga memberikan implikasi terhadap minat dan motivasi tenaga kesehatan yang tersebar pada masing-masing wilayah. Tenaga kesehatan yang diterima melalui rekrutmen secara terbuka cenderung memilih untuk bertugas pada daerah yang memiliki kondisi geografis, sosial dan ekonomi yang lebih berkembang.

Sementara itu, pada wilayah kecamatan yang masih memiliki kondisi geografis, sosial dan ekonomi yang belum berkembang cenderung diisi oleh tenaga PTT.

Sebaran kualifikasi yang belum merata ini menonjol terjadi pada wilayah kecamatan yang pada beberapa desanya masih terpencil, seperti misalnya pada wilayah kecamatan Punduh Pidada.

\section{Kualitas Pelayanan Kesehatan}

Kualitas dari sebuah layanan publik dapat dimaknai sebagai keluaran (output) dari proses yang berisikan sumberdaya dan mekanisme yang terdapat di dalam instansi pelayanan. Dalam konteks layanan kesehatan, maka kualitas pelayanan tersebut dapat diartikan sebagai hasil yang dicapai dari sumberdaya dan mekanisme pelayanan yang diselenggarakan oleh berbagai instansi pelayanan kesehatan. Dalam penelitian ini digunakan pencapaian indikator standar pelayanan minimum dalam sub bidang pelayanan kesehatan dasar yang merupakan ruang lingkup terbesar dalam pelayanan kesehatan masyarakat. Indikator ini digunakan karena telah dapat menggambarkan secara jelas perbandingan antara sasaran awal yang sebelumnya ditentukan oleh instansi pelayanan kesehatan itu sendiri, juga 
membandingkannya dengan realisasi yang bisa dicapai secara faktual oleh instansi tersebut. Hasil akhir yang secara jelas dan dapat dijadikan acuan awal adalah persentase yang diperoleh dari perbandingan antara sasaran awal dan realisasi yang diperoleh.

Rincian tingkat pencapaian dari indikator tersebut pada Kabupaten Pesawaran dapat dicermati dari dalam tabel 1.

Tabel 1

Pencapaian Indikator Standar Pelayanan Minimun (SPM)

Sub Bidang Pelayanan Kesehatan Dasar Kabupaten Pesawaran Tahun 2011.

\begin{tabular}{|c|c|c|c|c|}
\hline No & Indikator SPM & $\begin{array}{c}\text { Hasil/ } \\
\text { Realisasi }\end{array}$ & $\begin{array}{l}\text { Target/ } \\
\text { Sasaran }\end{array}$ & Pencapaian \\
\hline $\mathbf{A}$ & Pelayanan Kesehatan Dasar & & & \\
\hline 1. & Cakupan kunjungan ibu hamil K 4 & 8.550 & 10.466 & $81,69 \%$ \\
\hline 2. & Cakupan komplikasi kebidanan yang ditangani & 313 & 1.878 & $16,67 \%$ \\
\hline 3. & $\begin{array}{l}\text { Persentase cakupan pertolongan persalinan oleh } \\
\text { bidan atau tenaga kesehatan yang memiliki } \\
\text { kompetensi kebidanan. }\end{array}$ & 8.078 & 8.962 & $90,14 \%$ \\
\hline 4. & Cakupan pelayanan nifas & 8.066 & 17.070 & $47,25 \%$ \\
\hline 5. & $\begin{array}{l}\text { Cakupan neonatus dengan komplikasi yang } \\
\text { ditangani }\end{array}$ & 244 & 1.202 & $20,30 \%$ \\
\hline 6. & Cakupan kunjungan bayi & 6.229 & 8.535 & $72,98 \%$ \\
\hline 7. & $\begin{array}{l}\text { Cakupan Desa/ Kelurahan Universal Child } \\
\text { Immunization }\end{array}$ & 119 & 133 & $89,47 \%$ \\
\hline 8. & Cakupan Pelayanan anak balita & 17.796 & 38.369 & $46,38 \%$ \\
\hline 9. & $\begin{array}{l}\text { Cakupan pemberian makanan pendamping Asi } \\
\text { pada anak } \\
\text { Usia 6-24 bulan keluarga miskin }\end{array}$ & 2.379 & 2.677 & $88,87 \%$ \\
\hline 10. & Cakupan balita gizi buruk mendapat perawatan & 11 & 11 & $100 \%$ \\
\hline 11. & $\begin{array}{l}\text { Cakupan penjaringan kesehatan siswa SD dan } \\
\text { setingkat }\end{array}$ & - & - & - \\
\hline 12. & Cakupan peserta KB aktif & 56.354 & 81.021 & $69,55 \%$ \\
\hline \multirow[t]{6}{*}{13.} & $\begin{array}{l}\text { Cakupan penemuan dan penanganan penderita } \\
\text { penyakit }\end{array}$ & & & \\
\hline & a. AFP rate 100.000 penduduk $<15$ tahun & 1 & 119.947 & 0,83 \\
\hline & b. Penemuan penderita pnemonia balita & 159 & 4.691 & $3,39 \%$ \\
\hline & c. Penemuan pasien baru TB BTA positif & 187 & 686 & $27,26 \%$ \\
\hline & d. $\quad$ Penderita DBD yang ditangani & 52 & 52 & $100 \%$ \\
\hline & e. Penemuan penderita diare & 11.601 & 16.871 & $68,76 \%$ \\
\hline 14. & $\begin{array}{l}\text { Cakupan pelayanan kesehatan dasar masyarakat } \\
\text { miskin }\end{array}$ & 209.471 & 209.471 & $100,00 \%$ \\
\hline \multirow[t]{3}{*}{ B. } & Pelayanan Kesehatan Rujukan & - & - & - \\
\hline & $\begin{array}{l}\text { a.Cakupan pelayanan kesehatan rujukan pasien } \\
\text { masyarakat miskin }\end{array}$ & - & - & - \\
\hline & $\begin{array}{l}\text { b.Cakupan pelayanan gawat darurat level } 1 \text { yang } \\
\text { harus diberikan sarana kesehatan (RS) di } \\
\text { kabupaten* } \\
\end{array}$ & & & \\
\hline C. & Penyelidikan Epidemiologi dan Penanggulangan & & & \\
\hline
\end{tabular}




\begin{tabular}{|l|l|l|l|l|}
\hline & KLB & & & \\
\hline & $\begin{array}{l}\text { a.Cakupan Desa/Kelurahan mengalami } \\
\text { KejadianLuar Biasa epidemiologi }<24 \text { jam }\end{array}$ & 9 & 9 & $100,00 \%$ \\
\hline & \multicolumn{1}{|l|}{} & & & \\
\hline D. & $\begin{array}{l}\text { Promosi Kesehatan dan Pemberdayaan } \\
\text { Masyarakat }\end{array}$ & & & \\
\hline & a.Cakupan Desa Siaga Aktif & 39 & 133 & $29,32 \%$ \\
\hline
\end{tabular}

Sumber: Dinas Kesehatan Kab. Pesawaran, 2010

Dari tabel tersebut dapat dicermati pencapaian masing-masing cakupan pelayanan kesehatan yang dilaksanakan dari seluruh instansi pelayanan kesehatan. Dapat dilihat bila pada beberapa cakupan pelayanan kesehatan tersebut dapat mencapai atau mendekati target/ sasaran yang telah ditentukan, seperti dalam cakupan balita gizi buruk yang mendapat perawatan, cakupan kunjungan bayi, cakupan kunjungan ibu hamil K 4 dan cakupan pertolongan persalinan oleh bidan atau tenaga kesehatan yang memiliki kompetensi kebidanan. Hal ini sebenarnya dapat dipahami karena jumlah tenaga bidan yang memang memiliki persentase terbesar dibandingkan dengan jenis tenaga medis yang lainnya. Sementara itu terdapat juga beberapa jenis cakupan pelayanan kesehatan yang tidak mencapai atau bahkan berada jauh di bawah target yang telah ditentukan. Cakupan tersebut antara lain adalah Cakupan Pelayanan anak balita, Cakupan pemberian makanan pendamping Asi pada anak Usia 6-24 bulan keluarga miskin, Cakupan penjaringan kesehatan siswa SD dan setingkat dan beberapa cakupan lainnya. Meskipun juga dipengaruhi oleh faktor sosial masyarakat setempat, cakupan-cakupan yang tidak tercapai tersebut merupakan jenis cakupan yang membutuhkan kapasitas sumber daya dan proses kerja yang lebih aktif.
Jika melihat sebaran pencapaian masing-masing cakupan tersebut maka dapat dimaknai bahwa masih banyak cakupan pelayanan yang belum dapat dilaksanakan secara optimal. Kondisi tersebut dilatarbelakangi oleh kondisi sumberdaya pelayanan yang digunakan di dalam proses pelayanan kesehatan itu sendiri. Hal ini sebenarnya relevan dengan uraian pada bagian efektivitas dan efisiensi pelayanan kesehatan. Kondisi sumberdaya yang memberi pengaruh terhadap hasil layanan yang dilaksanakan oleh instansi kesehatan tersebut dapat dipahami dari beberapa pernyataan pelaksana pelayanan pada tingkat Puskesmas.

\section{c. Bidang Pendidikan}

\section{Kondisi Sumber Daya \\ Pelayanan Bidang Pendidikan Infrastruktur dan Prasarana Pendidikan}

Pendidikan merupakan salah satu faktor penting indikator keberhasilan pembangunan di daerah, sesuai dengan Undangundang No. 20 Tahun 2003 tentang Sistem Pendidikan Nasional, untuk meningkatkan mutu pendidikan baik tenaga pendidik maupun pelajar di Kabupaten Pesawaran saat ini Pemerintah Kabupaten Pesawaran sedang mengupayakan untuk merealisasikan anggaran pendidikan sebesar $20 \%$ dari APBD Pemerintah 
Kabupaten. Pesawaran. Berbagai Fasilitas pendidikan yang di Kabupaten Pesawaran sementara masih merupakan aset dari Kabupaten Induk Lampung Selatan saat ini kondisinya masih cukup baik dan mulai dari tingkat taman kanakkanak sampai dengan SLTA. Jumlah gedung sekolah yang ada tersebut terdiri dari TK sebanyak 60 Unit, tingkat SD sebanyak 306 unit, tingkat SLTP sebanyak 60 unit, tingkat SMU sebanyak 16 unit.

Jumlah gedung sekolah yang ada tersebut menampung siswa sekolah yang cukup banyak yaitu 70.033 orang, terdiri dari 50.852 orang siswa SD, selain sarana pendidikan dan jumlah siswa, jumlah tenaga pendidik guru di Kabupaten Pesawaran juga cukup banyak, pada tahun 2010 jumlah tenaga guru di Kabupaten Pesawaran tercatat sebanyak 2.882 Orang, terdiri dari Guru SD sejumlah 2000 orang, Guru SLTP sejumlah 668 orang, Guru SLTA sejumlah 214 orang dan Guru TK sejumlah 185 orang.

\section{Efektivitas dan Efisiensi Pelayanan Bidang Pendidikan}

\footnotetext{
Kondisi sumber daya yang terdapat di wilayah Kabupaten Pesawaran sebagai Daerah Otonom Baru pada saat ini menunjukkan bahwa masih terdapat banyak permasalahan yang bisa menjadi kendala dan tantangan bagi proses penyelenggaraan pendidikan di Kabupaten baru tersebut. Jika melihat kondisi infrastruktur yang masih dihadapkan kepada masalah kecukupan dan kelayakan sarana gedung sekolah, masalah ketersediaan sarana peralatan dan pendukung pembelajaran, kuantitas
}

tenaga pendidik yang berstatus pegawai negeri sipil (PNS) dan distribusi anggaran operasional yang masih terhambat oleh proses anggaran yang bertingkat, maka dapat dirangkum fakta bahwa hal-hal tersebut mempengaruhi derajat efektifitas kegiatan pendidikan secara menyeluruh. Kondisi-kondisi tersebut mempengaruhi jalannya proses penyelenggaraan pendidikan yang semestinya dapat berjalan dengan optimal. Secara jangka panjang, kondisi yang dihadapi tersebut dapat mempengaruhi kondisi kapasitas pendidikan sumber daya manusia Pesawaran yang berpotensi menghadapi kendala kompetitif dengan sumber daya manusia dari daerah sekitarnya.

Sebagai sebuah daerah otonom baru, Kabupaten Pesawaran juga memiliki pilihan solusi yang terbatas untuk mengatasi kondisi sumber daya yang belum berada pada tingkat memadai. Belum semua tenaga kependidikan telah mengikuti penyetaraan kualitas pendidikan, penataran guru mata pelajaran, pelatihan tenaga fungsional, penataran manejemen kepala sekolah dan kepala tata usaha. Namun demikian, dapat diketahui juga adanya beberapa langkah yang dilakukan oleh pemerintah Kabupaten guna mengatasi berbagai permasalahan tersebut. Dalam hal ketersediaan tenaga pendidik, langkah yang dilakukan berupa pelaksanaan penyetaraan kualitas pendidikan, penataran guru mata pelajaran, pelatihan tenaga fungsional, penataran manajemen kepala sekolah dan kepala tata usaha untuk meningkatkan mutu pendidikan, pelaksanaan program life skill akan diterapkan pada semua sekolah sehingga dapat 
menghasilkan sumber daya manusia berkualitas yang siap pakai dalam menghadapi dunia kerja.

Dilaksanakannya penataran kualifikasi tenaga kependidikan berupa penataran guru, kepala tata usaha, untuk mendukung mutu pendidikan, dilakukannya rekruitmen secara berkala terhadap tenaga honorer yang memenuhi syarat dan melaksanakan rekruitmen terbuka untuk memperoleh tenaga pendidik yang memiliki spesifikasi latar pendidikan yang tepat. Sementara itu, dalam hal ketersediaan infrastruktur dan sarana pelengkap khususnya jika dikaitkan dengan ketersediaan anggaran (antara lain dana untuk rehabilitasi gedung sekolah mulai SD/MI sampai dengan SMU/SMK belum semuanya dapat merehab gedung-gedung yang rusak) belum bisa optimal untuk diusahakan karena kendala anggaran yang terbatas pada APBD Kabupaten. Langkah yang dapat dilakukan dalam persoalan anggaran operasional yang terbatas adalah melalui pengajuan alokasi DAU yang lebih merinci kebutuhan kondisi daerah secara lebih detail. Namun demikian, upaya yang dilakukan oleh pemerintah kabupaten ini juga masih menunjukkan ketergantungan terhadap bantuan dari pemerintah pusat. Solusi konvensional yang justru menunjukkan bahwa daerah otonom baru memang sangat tergantung terhadap bantuan dari pemerintah pusat.

Kondisi-kondisi tersebut yang secara kumulatif memberikan pengaruh terhadap kemampuan instansi pendidikan secara keseluruhan untuk memberikan pelayanan secara efektif. Dengan mencermati uraian yang telah dipaparkan pada bagian sumber daya pelayanan pendidikan maka bisa dipahami jika pelayanan pendidikan di Kabupaten ini belum bisa berjalan secara efektif. Bila suatu pelayanan tidak efektif, maka secara berhubungan juga mengalami kondisi yang tidak mampu untuk bergerak secara efisien. Kondisi tidak efisien dalam hal pelayanan pendidikan di Kabupaten ini bukan terjadi dalam kadar yang berlebihan, namun justru terjadi sebagai akibat dari minimalnya sumber daya yang teralokasikan.

Secara umum, permasalahan yang dihadapi bidang pendidikan di Kabupaten Pesawaran sebagai Daerah Otonom Baru sebagai berikut

a. Dana untuk rehabilitasi gedung sekolah mulai SD/MI sampai dengan SMU/SMK belum semuanya dapat merehab gedung-gedung yang rusak.

b. Terbatasnya sarana pendidikan seperti alat pendidikan dan alat laboratorium di semua jenis jenjang pendidikan

c. Belum semua tenaga kependidikan telah mengikuti penyetaraan kualitas pendidikan, penataran guru mata pelajaran, pelatihan tenaga fungsional, penataran manejemen kepala sekolah dan kepala tata usaha

d. Terbatasnya jumlah dan masih rendahnya mutu buku/modul pendidikan dan buku bacaan perpustakaan

e. Masih rendahnya kualitas pendidikan agama dan budi pekerti di sekolah

f. Penanganan program pembinaan bidang pemuda dan olah raga masih sangat kurang

g. Masih kurangnya sarana perangkat pendataan 
h. Belum semua sekolah melaksanakan program life skill

i. Belum semua personil telah mendapatkan kesempatan mengikuti pelatihan penjenjangan jabatan baik tenaga administrasi maupun tenaga teknis edukatif

j. Masih sangat terbatasnya jumlah dan rendahnya mutu pendidikan luar sekolah

Atas permasalahan tersebut upaya yang harus ditempuh adalah sebagai berikut :

a. Peningkatan pembangunan unit gedung baru, ruang kelas baru dan rehabilitasi gedung SD/MI sampai dengan SMA/SMK akan sangat membantu dalam pelaksanaan program pemerataan memperoleh kesempatan pendidikan

b. Ditingkatkannya pengadaan sarana pendidikan seperti alat pendidikan dan alat laboratorium di semua jenis jenjang pendidikan untuk mendukung program peningkatan kualitas dan relevansi tenaga kependidikan

c. Pelaksanaan penyetaraan kualitas pendidikan, penataran guru mata pelajaran, pelatihan tenaga fungsional, penataran manajemen kepala sekolah dan kepala tata usaha untuk meningkatkan mutu pendidikan

d. Peningkatan jumlah dan dan peningkatan mutu buku/modul pendidikan dan buku bacaan perpustakaan

e. Peningkatan kualitas pendidikan agama dan budi pekerti di sekolah

f. Peningkatan penangan program pembinaan bidang pemuda dan olah raga

g. Perlu adanya peningkatan jumlah sarana perangkat pendataan untuk mendukung pelaksanaan revitalisasi data base pendidikan, pemetaan dan inventarisasi pendidikan

h. Perlu ditingkatkannya jumlah dan mutu pelaksanaan pendidikan luar sekolah yaitu Kejar paket A setara SD, Kejar paket B setara SMP dan Kejar paket C setara SMA

\subsection{Faktor-Faktor Yang Mempengaruhi Kondisi Pelayanan Publik.}

\section{a. Struktur Organisasi dan Penyelenggaraan Layanan}

Dapat dicermati bahwa Pemerintah Kabupaten Pesawaran saat ini sudah menerapkan Peraturan Pemerintah Nomor 41 tahun 2007 Tentang Pedoman Pembentukan Struktur Organisasi Pemerintah Daerah. Struktur yang dibentuk dengan dasar peraturan tersebut berlaku dalam wujud hasil berupa struktur organisasi dan tata laksana organisasi pada keseluruhan instansi di Pemerintah Kabupaten Pesawaran, termasuk Dinas Pendidikan. Dikemukakan oleh Sekretaris Dinas Pendidikan Kabupaten Pesawaran bahwa dinas yang mengelola sektor pendidikan itu dulu sebelum penerapan PP 41 Tahun 2007 masih digabung menjadi Dinas Pendidikan, Kebudayaan, Pemuda dan Olahraga. Dapat dilihat dari namanya bahwa dinas yang mengabungkan beberapa lingkup wilayah tersebut nampak memiliki aktivitas yang cukup luas dan tidak sekedar berfokus kepada pengelolaan pendidikan masyarakat. Selanjutnya diketahui bahwa struktur yang terbentuk dengan cakupan seperti dahulu itu menjadikan pergerakan dinas menjadi rumit, karena banyak urusan dan bidang kerja yang harus dikelola. Namun 
demikian, dapat mereka pahami juga bahwa struktur yang sempat terbentuk dahulu itu dikarenakan kondisi sumber daya yang memang belum mencukupi untuk mendistirbusikan tugas-tugas itu secara spesifik pada masing-masing institusi kerja. Struktur organisasi yang sekarang lebih memfokuskan pelaksanaan urusan pendidikan kepada satu institusi yaitu Dinas Pendidikan. Dalam struktur organisasi yang sekarang ini terdiri empat bidang, yaitu Bidang Pendidikan Dasar, Pendidikan Menengah, Bidang Gedung dan Bidang Tenaga Kependidikan. Masing-masing Kepala Bidang itu kemudian membawahi beberapa seksi-seksi yang dipimpin oleh seorang Kepala Seksi. Struktur yang lebih fokus ini dirasakan lebih efektif dalam mengelola pendidikan di wilayah Pesawaran.

Namun demikian, kendala yang terjadi dalam penyelenggaraan tugas dan fungsi tersebut dapat diatasi melalui mekanisme rapat kerja pada masing-masing dinas dan dikuatkannya mekanisme pengendalian oleh pimpinan dinas dalam pelaksanaan urusan-urusan yang diselenggarakan oleh Dinas Pendidikan. Hal inilah yang dianggap masih dapat mengatasi permasalahan kinerja sektor pendidikan pada dinas Pendidikan tersebut.

\section{b. Kinerja Instansi Layanan}

Sebagai instansi yang secara langsung berhubungan dengan masyarakat dalam rangka pemberian layanan pendidikan, kinerja sekolahsekolah merupakan suatu hal yang sangat penting. Kinerja sekolahsekolah ini yang nantinya akan menentukan keberhasilan pengelolaan pendidikan pada wilayah Pesawaran dan secara jangka panjang akan menjadi penentu kualitas sumber daya manusia yang terdapat pada wilayah Pesawaran. Karena itu perlu dicermati pula kinerja sekolah-sekolah tersebut dalam konteks Kabupaten Pesawaran sebagai sebuah daerah otonom baru.

Sebagai daerah otonom baru dengan segala keterbatasan sumber daya terutama dalam hal pendanaan (tidak adanya Dana Alokasi Khusus) nampak menghasilkan kinerja yang masih kurang optimal. Beberapa sekolah-sekolah yang menjadi sumber informasi bagi penelitian ini juga mengemukakan bahwa kendalakendala yang dihadapi dalam penyelenggaraan pembelajaran di sekolah-sekolah mereka adalah kelengkapan-kelengkapan sarana dan prasarana pendidikan seperti gedunggedung sekolah yang sudah harus di rehab, terutama gedung Sekolah Dasar. Selain itu kendala yang juga secara riil dihadapi adalah kekurangan guru yang terjadi pada sekolah-sekolah di kecamatan yang belum terlalu maju.

$$
\text { Melihat kendala-kendala }
$$

tersebut, Dinas Pendidikan dan sekolah-sekolah yang dihadapkan kepada kendala tersebut merumuskan beberapa langkah-langkah yang berguna untuk mengatasi kendala tersebut. Dinas Pendidikan misalnya melakukan pengajuan bantuan kepada Pemerintah Provinsi dalam penanganan beberapa kendala yang dapat dibantu dari pendanaan APBD Provinsi. Sementara itu dalam penanganan sumber daya pendidik, penanganan terhadap kendala tersebut dilakukan secara bersama antara Dinas Pendidikan, sekolahsekolah dan dibantu dengan komite 
sekolah. Upaya yang dihasilkan dari penanganan bersama tersebut diantaranya melalui pengangkatan guru honorer.

Kondisi yang sama juga terjadi dalam sektor kesehatan. Dinas Kesehatan yang bertanggung jawab dalam pengelolaan sektor kesehatan di Kabupaten Pesawaran tersebut dihadapkan kepada permasalahan sumber daya anggaran dan berimplikasi kepada kondisi beberapa sumber daya pelayanan yang terdapat pada tingkat Puskesmas. Kepala Dinas Kesehatan mengemukakan bahwa kondisi perkembangan masyarakat di Pesawaran menuntut perkembangan yang juga seimbang dalam pembangunan sarana kesehatan masyarakat di wilayah Pesawaran. Kebutuhan yang cukup luas inilah yang dirasakan belum dapat diimbangi dengan memadai dalam anggaran kesehatan pada Dinas Kesehatan Kabupaten Pesawaran.

Dikemukakan juga bahwa dalam beberapa lingkup kegiatan Dinas Kesehatan belum dapat diselenggarakan secara maksimal karena kendala pendanaan yang harus dihadapi oleh mereka. Kegiatan-kegiatan yang belum terwujud tersebut diantaranya adalah kegiatan penyuluhan, pembinaan instansi sehat dan upaya pencegahan penyakit pada beberapa wilayah potensial penyakit. Kegiatankegiatan ini yang dikemukan sebagai aspek penting dalam kesehatan namun belum tercakup secara menyeluruh dalam penanganan kesehatan masyarakat di wilayah Pesawaran. Melihat kondisi dari sektor pendidikan dan sektor kesehatan tersebut dapat dicermati bahwa masing-masing instansi pelayanan dalam sektor pendidikan dan sektor kesehatan mengalami kendala anggaran. Kendala anggaran tersebut kemudian berimplikasi terhadap kondisi beberapa sumber daya lainnya dan berpotensi untuk mempengaruhi kinerja pelayanan masing-masing instansi

pelayanan tersebut.

\section{PENUTUP}

\subsection{Simpulan}

1. Tatakelola administrasi pemerintahan yang baik di Kabupaten Pesawaran melalui pelayanan publik di bidang kependudukan dan catatan sipil antara lain Pelatihan tenaga teknis SIAK, pemutahiran data penduduk/data base melalui teknologi SIAK Off-Line, mengadakan pelatihan/diklat petugas pendaftaran penduduk dan diklat aparatur dibidang Administrasi Kependudukan serta penerapan pprogram e-KTP.

2. Tatakelola administrasi pemerintahan yang baik melalui pelayanan publik di bidang pendidikan antara lain, pelaksanaan program life skill pada semua sekolah sehingga dapat menghasilkan sumber daya manusia berkualitas yang siap pakai dalam menghadapi dunia kerja peningkatan pembangunan unit gedung baru, ruang kelas baru dan rehabilitasi gedung sekolah, peningkatan pengadaan sarana pendidikan seperti alat pendidikan dan alat laboratorium di semua jenis jenjang pendidikan untuk mendukung program peningkatan kualitas dan relevansi tenaga kependidikan.

3. Tatakelola administrasi pemerintahan yang baik di 
Kabupaten Pesawaran sebagai daerah otonom baru melalui pelayanan publik di bidang kesehatan masyarakat antara lain melalui penyempurnaan manajemen pelaksanaan program yang efektif dan efisien, meningkatkan kinerja dalam pelaksanaan program pembangunan kesehatan, meningkatkan profesionalisme dan kualitas tenaga kesehatan dalam rangka meningkatkan kualitas pelayanan kepada masyarakat, meningkatkan advokasi ke Pemerintah Daerah dan Dinas Kesehatan Provinsi serta Kementerian Kesehatan untuk meningkatkan pemenuhan sumberdaya khususnya pembiayaan kesehatan, meningkatkan upaya preventif dan promotif dalam pelaksanaan program pembangunan kesehatan.

\subsection{Saran}

Sebagai daerah otonom baru, Kabupaten Pesawaran senantiasa berusaha memberikan bentuk-bentuk layanan publik yang prima kepada masyarakatnya, persoalan pengganggaran hendaknya tidak mempengaruhi pemberian bentukbentuk pelayanan publik kepada masyarakat, karena dengan tidak maksimalnya kapasitas anggaran, bukan berarti mengakibatkan lemahnya kapasitas penyelenggaraan pemerintahan dan pemberian layanan publik yang secara langsung harus dilaksanakan oleh Pemerintah Kabupaten Pesawaran seiring dengan semangat reformasi birokrasi.

\section{DAFTAR PUSTAKA}

Alwasilah, A. Chaedar. 2002. Pokoknya Kualitatif: Dasardasar Merancang dan Melakukan Penelitian Kualitatif. Pustaka Jaya. Jakarta.

Djaenuri, Aries. 2003. Sistem Pemerintahan Desa. Universitas Terbuka. Jakarta.

Hendrarso, E.S. 2005. Penelitian Kualitatif: Suatu Pengantar, dalam Metode Penelitian Sosial: Berbagai Alternatif Pendekatan, editor: Bagong Suyanto. Penerbit Kencana. Jakarta.

Neta, dkk. 2008. Formulasi Strategi Daerah Otonom Baru Dalam Mengatasi Faktor-Faktor Penghambat Otonomi Daerah. Hasil Penelitian.Universitas Lampung.

Lembaga Administrasi Negara Republik Indonesia. 1996. Sistem Administrasi Negara Republik Indonesia. Jilid II Cetakan Kedua Edisi Ketiga. PT Toko Gunung Agung. Jakarta.

Lembaga Administrasi Negara Republik Indonesia. 1997. Sistem Administrasi Negara Republik Indonesia. Jilid I Cetakan Ketiga Edisi Ketiga. PT Toko Gunung Agung. Jakarta.

Ma'arief, S. 2009. Penyusunan Model Reformasi Pelayanan Publik Dalam Rangka Reinventing Govenrment Di Daerah Hasil Pemekaran, (Studi Kasus Pembentukan Kabupaten Pringsewu Provinsi Lampung). Hasil 
Penelitian, Universitas

Lampung.

Milles, M. B. \& M. A. Hubberman. 1992. Analisis Data

Kualitatif: Terjemahan. UI Press. Jakarta.

Moleong, Lexy. 2000. Metode Penelitian Kualitatif. PT Remaja Rosda Karya: Bandung.

Mulyana, N. 2009. Model Pengahantaran Pelayanan Publik Pada Daerah Otonom Baru. Hasil Penelitian, Universitas Lampung

Prasojo, Eko. 2007. Perkembangan Ilmu Administrasi dan Implikasinya pada Pendidikan Tinggi Abad 21. Seminar dan Lokakarya Nasional Reformasi Pendidikan Tinggi Ilmu Administrasi Abad 21, Kerjasama Persadi, FIA Unibraw, dan BKLPIAI. Malang.

Suradinata, Ermaya. 1998. Administrasi Lingkungan dan Ekologi Pemerintahan dalam Pembangunan. $\mathrm{CV}$. Ramadan. Bandung.

Wijaya, HAW. 2002. Pemerintahan Desa dan Administrasi Desa Menurut Undang-Undang No. 5 Tahun 1979. PT Raja Grafindo Persada. Jakarta. 